\title{
PRODUCTION OF ORNAMENTAL PLANTS AND CUT FLOWERS IN PERI-URBAN AREAS: AN ECONOMIC AND ENVIRONMENTAL ANALYSIS OF THE BARCELONA METROPOLITAN REGION, SPAIN
}

\author{
XAVIER RECASENS \& OSCAR ALFRANCA \\ Departament Eng. Agroalimentària i Biotecnologia, Universitat Politècnica de Catalunya (Barcelona tech), Spain
}

\begin{abstract}
Ornamental plants and floral plants are not usually considered in research works on urban agriculture. On the contrary, the main stream of research is focused on food production. An essential feature of ornamental plant markets is that they are global. Most of consumers ornamental plants and cut flowers are located in Europe, United States of America and Japan, and the emerging producers are located in South America and Africa. Ornamental crops present a very high added value, if they are compared with vegetables and fruits, or crops like cereals. Ornamental plants and cut flowers production needs a high level of technology to control the irrigation system (soilless culture), the environment (temperature, humidity, light) and the postharvest. The aim of this study is the evaluation of the technological level used by urban farmers. More specifically, this objective can be achieved through the next questions: How to be competitive in the ornamental global market? Which are the advantages of these farmers being located in urban areas? Which channels do they use to sell their production? A semi - structured survey was conducted of ornamental and cut flowers farmers in Barcelona Metropolitan Region (Catalonia, Spain). The survey was approved by the working group of Entrepreneurial Models of Urban Agriculture within the framework of the European project Cost Action TD 1106 Urban Agriculture Europe.

Keywords: urban agriculture, urban farming, ornamental plants, cut flowers, urban fringe.
\end{abstract}

\section{INTRODUCTION}

The economic viability of farms can be conditioned by the types of crops that take place and the agricultural activities that are developed. The limiting factor is often the surface of these farms. In the case of farms with little surface of farmland, one of the strategies used is the specialization of agriculture [1]. This specialization can go through the intensification of agriculture, such as vegetable crops and ornamental plants [2]. It is accompanied by technology, such as protected crops, irrigation systems and climate control. The ornamental plant crops are labour intensive throughout the year and have a high return in terms of production value per $\mathrm{m}^{3}$ of water consumed if they are compared with other crops [3].

The consumption of flowers and ornamental plants is related to emotional needs [4], [5], to feelings, to the quality of life, and to cultural aspects [6]. Flowers and herbs are starting to be introduced in the diet [7].

The global value of ornamental plants and cut flowers is estimated between 100-150 billion €/year [8]. Chandler and Brugliera [9] define three main regions in the world consumers and producers of flowers and ornamental plants. These regions are: Europe, the United States of America and Japan.

Ornamental crops (cut flowers or potted plants), are intensive crops. They are produced during all year, more than one culture simultaneously and more than one crop/ year in the same plot. These intensity crops, to be optimal in the use of resources, to be competitive in a global market and to be respectful to the environment require that these farm holdings are 
intensive in the use of technology. This technology can be divided into: using plant material, efficiency in the use of irrigation and fertilization, and climate control.

The use of improved plant material leads to a saving in resources used by the crop and to a reduction in pesticides applied [10], as well as to a uniformity of production, dimensions and colours.

To produce intensive crops requires a high amount of water compared with rainfall crops. The control of irrigation systems represents a saving water and electricity consumption, which represent an increase of productivity [11], [12]. One of the ways to reduce consumption of water and nutrients in soilless culture is the recirculation of the nutrient solution [13].

Much of the cultivation of ornamental plants is carried out under protected crops. This management allows to maintain a continuous production during all year without being affected by seasonal changes. For Kolokotsa et al. [14], cultivation under protected cultivation, is the way to optimize the production per unit of energy consumed.

There are several labels and certificates that allow to certify the good management of the practices carried out for the ornamental plant producers [15]. There are two types of labels and certifications: labels that are recognised by the final consumer and labels that do not arrive to the final consumer such as business to business (BtoB).

Urban agriculture is defined as the agriculture that is carried out in the city or in its surroundings [16], [17]. While none of the definitions exclude, per se, non-food crops, most of the literature focuses on food production. Pölling et al. [18] focused their study on the business models of urban agriculture in the Ruhr region of Germany. All the farms analysed are related to food production. Zasada [19] mentions the production of regional agricultural products as a strategy for suburban farms.

Peri-urban farms suffer a strong anthropogenic pressure, related to other alternative land uses. The viability of these farms is subject to the opportunities given by the proximity of the city and its citizens [20]. Peri-urban farms need to adapt, innovate and take advantage of their location close to the cities [21].

As we have seen, the market of ornamental plants and cut flowers is a global market. We are talking about a very competitive market where the efficiency in the use of resources can be key to the survival of these farms. Aspects as expertise, use of technology, and localisation allow an optimum use of resources. The city could be the key to this type of agricultural activities.

For this reason, the main aims of the study are:

- To study if the specialized crops are an alternative in the peri-urban areas.

- To know which the level of use of technology in cut flowers and ornamental plants farm holdings, and if these farms take advantage of their location in a peri-urban area.

\section{MATERIAL AND METHODS}

In the study, a survey of the different cut flower and ornamental plant farms located in Barcelona Metropolitan Region was conducted, and nine farm holdings responded.

\subsection{Study area}

The metropolitan region of Barcelona (BMR) is located in the North East of the Iberian Peninsula. It has a population of 4,793,592 inhabitants, with an area of 2,350.9 $\mathrm{km}^{2}$ and a density of 2.039 inhabitants $/ \mathrm{km}^{2}$. The main cities are Barcelona, L'Hospitalet de Llobregat, 
Badalona, Terrassa, Sabadell and Mataró. The main crops of the region are cereals, vegetables, ornamental crops and vineyards.

In BMR, according to data from the Department of Agriculture of Catalonia [22], there are 534 has. (2015) dedicated to ornamental crops.

The cultivation of ornamental plants and cut flowers in the region dates back from 1832 [23]. The strong expansion of cultivation of ornamental plants dated from the 20s of the 20th century [23].

The study area, according to Marfà [24], presents good weather conditions to carry out intensive crops (an average temperature of $16^{\circ} \mathrm{C}$ and more than 900 light hours per year).

\subsection{Surveys}

To analyse the ornamental plant farm holdings, we employ a semi-structured survey. By following a predetermined script, these types of surveys allow respondents to express their point of view about the issues that they consider appropriate.

The survey form has been elaborated during meetings of the European COST-Action Urban Agriculture Europe project, TD 1106, held by the Entrepreneurial Models of Urban Agriculture working group [25]. This survey model was created specifically for urban farms, and the questionnaire encompasses farms ranging from those that have only social aims to those with only profit motives. The advantage of using this interview model is that a wide range of urban farms can be represented, and it also establishes a European model for surveying urban agriculture. It would be useful to conduct comparisons between different urban farms around European cities as well as cities in developed countries.

The survey includes 49 questions and is divided into ten parts: 1) Brief description of the farm (name, surface, location, year of establishment, type of crop and crop management). 2) What is/are the purposes of your activities? This question is aimed at understanding the objectives of the owners for participating in agricultural activities (commercial, selfconsumption, livelihood, education, environmental, social, leisure-wellness, maintaining cultivated land, research and development). 3) Short description of the characteristics of the

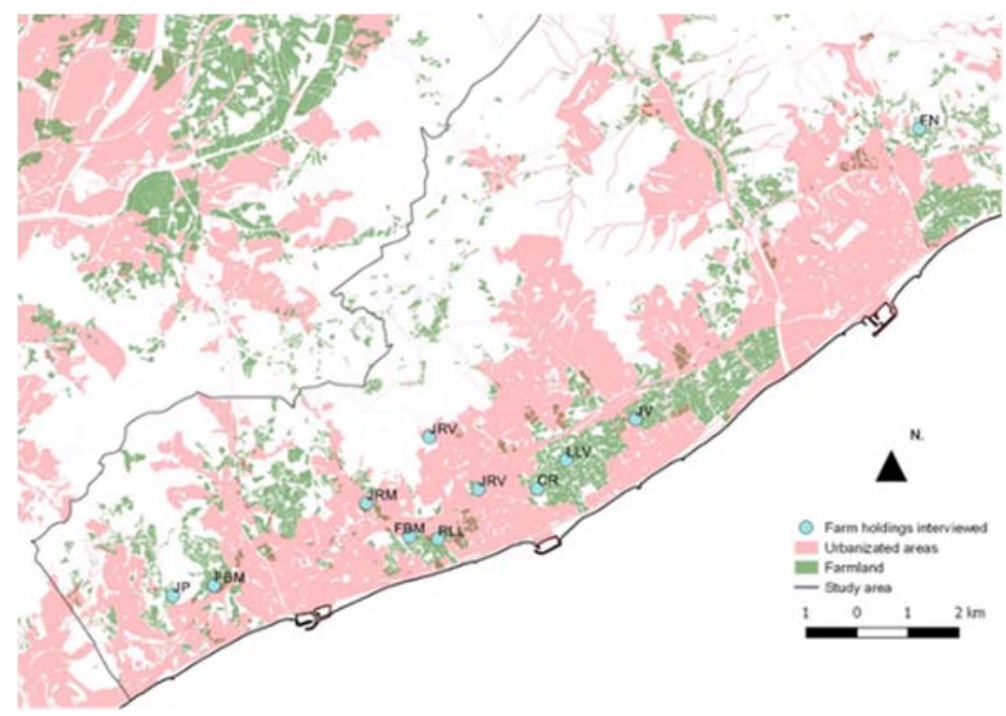

Figure 1: Detailed locations of farm holdings interviewed. 
Table 1: Value of each economic and social benefit indicator.

\begin{tabular}{|c|c|c|c|c|c|c|}
\hline \multirow{2}{*}{ Service } & \multicolumn{5}{|c|}{ Indicator value } \\
\cline { 2 - 7 } & 0 & 1 & 2 & 3 & 4 & 5 \\
\hline Production value: $€$ /year & $<1,000$ & $\begin{array}{c}1,000- \\
5,000\end{array}$ & $\begin{array}{c}5,001- \\
20,000\end{array}$ & $\begin{array}{c}20,001- \\
100,000\end{array}$ & $\begin{array}{c}100,00- \\
500,000\end{array}$ & $>500,000$ \\
\hline $\begin{array}{c}\text { Number of full time } \\
\text { jobs/year }\end{array}$ & 0 & $<0.25$ & $0.26-1$ & $2-5$ & $6-10$ & $>10$ \\
\hline $\begin{array}{c}\text { Number of full time jobs } \\
\text { without salary/year }\end{array}$ & 0 & $<0.25$ & $0.26-1$ & $2-5$ & $6-10$ & $>10$ \\
\hline $\begin{array}{c}\text { Educational activities: } \\
\text { person hours/year }\end{array}$ & 0 & $<100$ & $\begin{array}{c}100- \\
1,000\end{array}$ & $\begin{array}{c}1,001- \\
5,000\end{array}$ & $\begin{array}{c}5,001- \\
10,000\end{array}$ & $>10,000$ \\
\hline $\begin{array}{c}\text { Social activities: person } \\
\text { hours/year }\end{array}$ & 0 & $<100$ & $\begin{array}{c}100- \\
1,000\end{array}$ & $\begin{array}{c}1,000- \\
5,000\end{array}$ & $\begin{array}{c}5,001- \\
10,000\end{array}$ & $>10,000$ \\
\hline $\begin{array}{c}\text { Managed green open } \\
\text { space: ha }\end{array}$ & 0 & $<0.1$ & $0.1-1.0$ & $1.1-10.0$ & $\begin{array}{c}10.1- \\
50.0\end{array}$ & $>50$ \\
\hline $\begin{array}{c}\text { Production agro- } \\
\text { biodiversity: number of } \\
\text { different varieties }\end{array}$ & 1 & $2-5$ & $6-10$ & $11-20$ & $21-30$ & $>30$ \\
\hline $\begin{array}{c}\text { Cultural Landscape: } \\
\text { maintenance costs of } \\
\text { preserved historical } \\
\text { buildings in } € \text { /year }\end{array}$ & 0 & $<5,000$ & $\begin{array}{c}5,001- \\
20,000\end{array}$ & $\begin{array}{c}20,001- \\
50,000\end{array}$ & $\begin{array}{c}50,001- \\
100,000\end{array}$ & $>100,000$ \\
\hline
\end{tabular}

farm (municipality, distance to urban land, soil type according to urban planning). 4) Markets and marketing (Which products are marketed? Which customers are targeted? What expectations do customers have? Which marketing channels are used? What makes your product different compared to other producers or other areas?). 5) Institutional environment (Is the farm receiving grants or support from any administration? Is there any relationship between farms/ wineries, and what type of support would be needed?). 6) Success factors: Which factors make your activities successful? 7) What are the main problems facing your operations? 8) Economic and social benefits (production value; job creation; volunteer, educational, and social; preservation of the agricultural surface, agro-biodiversity and cultural landscape). 9) Natural and cultural heritage. 10) Owner profile (age, level of education, level of family involvement in the project and how he/she decided to enter into peri-urban agricultural production).

All interviews were conducted in person at the farm holdings by appointment. Prior to the interview, a brief description of the study was provided. The duration of the interview was between 25 and 50 minutes, but the time varied depending on the availability of the respondent. All interviews were carried out between January and July 2017.

\section{RESULTS}

This section presents a brief description of the farm holdings. The results concerning the technology used, level of investment and marketing and benefits to be peri-urban are also described. 


\subsection{Main features}

The following table is a brief characterization of the farm holdings interviewed. Six of the nine farms interviewed have more of 40 years of existence, and three of them have less than 40 years. The average age of the owners, managers or directors is 48.44 years. The average of total farm area is $38,133.33 \mathrm{~m}^{2}$, while the average of cultivated surface is $26,688.89 \mathrm{~m}^{2}$. The farmers interviewed are engaged in almost all range of products related to ornamental crops even the most innovative production of edible flowers and herbs.

Table 2: Main features of the ornamental plants and cut flowers holdings interviewed.

\begin{tabular}{|c|c|c|c|c|c|}
\hline Farm holding & $\begin{array}{c}\text { Year of } \\
\text { foundation }\end{array}$ & $\begin{array}{c}\text { Manager's } \\
\text { age }\end{array}$ & $\begin{array}{c}\text { Total } \\
\text { surface }\left(\mathrm{m}^{2}\right)\end{array}$ & $\begin{array}{c}\text { Crop surface } \\
\left(\mathrm{m}^{2}\right)\end{array}$ & Crops \\
\hline FBM & 1996 & 46 & 60,000 & 20,000 & Cut flowers \\
\hline JRM & 2007 & 47 & 1,200 & 1,200 & Edible flowers \\
\hline JV & 1940 & 61 & 30,000 & 30,000 & Cut flowers \\
\hline FN & 1970 & 48 & 50,000 & 50,000 & $\begin{array}{c}\text { Cut flowers/pot } \\
\text { plants }\end{array}$ \\
\hline RLL & 1917 & 45 & 20,000 & 20,000 & Cut flowers/foliage \\
\hline JP & 1939 & 45 & 27,000 & 27,000 & Pot plants \\
\hline JRV & 1972 & 51 & 60,000 & 20,000 & $\begin{array}{c}\text { Seedlings/edible } \\
\text { flowers and herbs }\end{array}$ \\
\hline CR & 1985 & 53 & 45,000 & 35,000 & Seedlings \\
\hline LLV & 1906 & 40 & 50,000 & 37,000 & Pot plants \\
\hline
\end{tabular}

Table 3: Economic and social benefit indicator.

\begin{tabular}{|c|c|c|c|c|c|}
\hline Farm holding & $\begin{array}{c}\text { Production } \\
\text { value }\end{array}$ & Full time jobs & $\begin{array}{c}\text { Educational } \\
\text { activities }\end{array}$ & $\begin{array}{c}\text { Social } \\
\text { activities }\end{array}$ & $\begin{array}{c}\text { Agro- } \\
\text { biodiversity }\end{array}$ \\
\hline FBM & 4 & 4 & 0 & 1 & 2 \\
\hline JRM & 2 & 1 & 0 & 0 & 5 \\
\hline JV & 4 & 5 & 1 & 1 & 4 \\
\hline FN & 5 & 5 & 2 & 1 & 2 \\
\hline RLL & 3 & 3 & 0 & 0 & 3 \\
\hline JP & 5 & 4 & 0 & 1 & 5 \\
\hline JRV & 5 & 5 & 1 & 2 & 3 \\
\hline CR & 5 & 5 & 2 & 1 & 5 \\
\hline LLV & 5 & 4 & 1 & 0 & 3 \\
\hline Average & 4.22 & 4.00 & 0.78 & 0.78 & 3.56 \\
\hline $\begin{array}{c}\text { Standard } \\
\text { deviation }\end{array}$ & 1.09 & 1.32 & 0.83 & 0.67 & 1.24 \\
\hline
\end{tabular}


To serve their demand requires to produce a wide range of products: more than 20 different varieties are cultivated (Table 3 ). The demand of cut flowers and pot plants is associated with trends or fashions.

The interviewed farms employ a high amount of labour. Most of them have more than 6 equivalent workers and have a high production value, over 100,000 €/year. Only FN CR JRV offer social activities: they receive visits with educational or commercial purposes.

\subsection{Technology and investment}

All farms use selected plant material (Table 4). All the farms are using protected crops, to provide a high production quality and constant production during all year. The greenhouses most used are built with metal and plastic or metal and glass, but there are some farms that use wood structures.

The medium used by most of them is soilless culture, even there are two farms, JRM and $\mathrm{JV}$, which still grow directly in soil a part of their production.

The use of greenhouses and climate control is a step to produce during all year. All farms surveyed carry out climate control. This climate control is controlled by software that allows to fix humidity, temperature and radiation. Despite the mild climate of the area of study, it is necessary to use heating during the winter months (October-March). All the farms, apart from JRM and RLL, use heating systems.

The use of specific machinery to reduce labour used in the farms interviewed. All, except for JRM, JV and RLL, used machinery in some steps of their production system (automatic system of flower classification, of potted plants planting and pruning). The use of machinery allows them to reduce the needs of work and to be more efficient.

The investment levels vary greatly depending on farm holding. For the low technology farms are of $1,000 € /$ year, while for the higher technology farms they vary varies between $18,000-80,000 € /$ year. Some of the producers have commented that the levels of investment in the year 2008 were higher than 2017.

Table 4: Characterization of the technology used and annual investment.

\begin{tabular}{|c|c|c|c|c|c|c|c|}
\hline $\begin{array}{c}\text { Farm } \\
\text { holding }\end{array}$ & $\begin{array}{c}\text { Selected } \\
\text { material }\end{array}$ & Greenhouse & $\begin{array}{c}\text { Crop } \\
\text { media }\end{array}$ & Fertigation & Recirculation & $\begin{array}{c}\text { Climate } \\
\text { control }\end{array}$ & $\begin{array}{c}\text { Annual } \\
\text { investment } \\
(2017)\end{array}$ \\
\hline FBM & Yes & Yes & Soilless & Yes & No & Yes & $25,000 €$ \\
\hline JRM & Yes & Yes & $\begin{array}{c}\text { Soil and } \\
\text { soilless }\end{array}$ & No & No & No & $1,000 €$ \\
\hline JV & Yes & Yes & $\begin{array}{c}\text { Soil and } \\
\text { soilless }\end{array}$ & Yes & No & Yes & $20,000 €$ \\
\hline FN & Yes & Yes & Soilless & Yes & Yes & Yes & $60,000 €$ \\
\hline RLL & Yes & Yes & Soilless & Yes & No & No & $1,000 €$ \\
\hline JP & Yes & Yes & Soilless & Yes & No & Yes & $30,000 €$ \\
\hline JRV & Yes & Yes & Soilless & Yes & Yes & Yes & $18,000 €$ \\
\hline CR & Yes & Yes & Soilless & Yes & No & Yes & $80,000 €$ \\
\hline LLV & Yes & Yes & Soilless & Yes & No & Yes & $60,000 €$ \\
\hline
\end{tabular}




\subsection{Marketing and benefits to be peri-urban}

The main aim of the farms interviewed is commercial. All farms want to sell their production. We can distinguish two groups of producers: those who sell the finished product to other producers like JRV and CR and those who sell the finished product. The producers who sell the finished product, their customers are mostly florists and ornamental plant wholesalers. The channels that are used can be: directly to the florist or wholesaler, in the flower markets or in the farm. There are also producers such as FN, JP and LLV that use a commercial network. There are producers like JP that sells 100\% of its production through the cooperative. This cooperative scheduled its production throughout the year.

In the case of producers of edible flowers their sale is direct to restaurants, shops and supermarkets.

There is no pattern of sales. There are producers who sell the $100 \%$ of its production in Catalonia, such as FBM, JRM and JRV-edible flowers. Others such as JV and RLL, with their sales in a local level (Catalonia) represent more than $50 \%$ in volume. The other producers sell part of their production to the rest of Spain and abroad. These sales can reach $50 \%$ or more.

There is only one farm with the label organic production and four of them have a certification of production quality and respectful with the environment, issued by a company (BtoB). These certifications are required to sell abroad.

Apart from JRM, which was installed in the year 2007, the rest of the farms were established more than 20 years ago in the area. Many of the interviewees commented that they or the founders were not located in the urban fringe, rather that the city grew to their property.

All of them are agree on the importance of the proximity to Barcelona city. Barcelona citizens' demand of plants and flowers is an advantage for them. Within the study area there are two markets of producers of flowers and ornamental plants. FBM, JV, RLL and FN sell their production in these markets. Also, the good infrastructure of communications with the rest of Catalonia, Spain and Europe are important factors to be considered, especially for FN, JP, JRV, CR and LLV.

\section{DISCUSSION}

The farmland in the study area has been reduced in the past 20 years. The reduction of the agricultural surface is due to the growth of the urban space. The population has moved out of the city of Barcelona. According to Rubiales et al. [26], BMR presents an output of population from major cities, to other municipalities less dense, such as those in the study area, with more environmental quality and less proportion of population of low - middle class.

As we can see in Table 2, we are talking about small farms of less than 3 ha. With this low surface the farm holdings need to produce crops with a high value of production $(€ / \mathrm{ha})$. According to the National Agricultural Accounting of the Ministry of Agriculture, the standard production coefficients [27], expressed in $€ /$ ha, for Catalonia are: 10,264.70 €/ha for vegetables, $86,421.82 € /$ ha for vegetables - under greenhouse, $106,181.58 € /$ ha for cut flowers and pot plants and $286,612.03 € /$ ha for cut flowers and pot plants - under greenhouse. The ornamental crops are the crops with a high value per surface unit in Catalonia.

Contrary to what it is described in Polling et al. [18], Zasada [19] and Recasens et al. [28], none of the farms interviewed offer activities related to agriculture. All of them received visits, but without being unrelated to the business model. These visits are offered to Universities, Agrarian Schools, Customers and Suppliers. 
Table 5: Marketing and labelling.

\begin{tabular}{|c|c|c|c|c|c|}
\hline \multirow{2}{*}{$\begin{array}{l}\text { Farm } \\
\text { holding }\end{array}$} & \multicolumn{3}{|c|}{ Markets (2017) } & \multirow{2}{*}{ Market channels } & \multirow{2}{*}{ Labelling } \\
\hline & Catalonia & Spain & Abroad & & \\
\hline FBM & Yes & No & No & Flower markets, directly to florists & No \\
\hline JRM & Yes & No & No & Directly to shops and restaurants & No \\
\hline JV & Yes & Yes & Yes & $\begin{array}{c}\text { Flower markets, directly to florist and } \\
\text { wholesalers }\end{array}$ & No \\
\hline FN & Yes & - & Yes & $\begin{array}{c}\text { Flower markets, directly to florist and } \\
\text { commercial network }\end{array}$ & Yes (BtoB) \\
\hline RLL & Yes & Yes & Yes & Flower markets & No \\
\hline JP & Yes & Yes & Yes & Cooperative & Yes (BtoB) \\
\hline JRV & Yes & Yes & Yes & $\begin{array}{l}\text { Seedlings: directly to producers and } \\
\text { commercial network. } \\
\text { Edible flowers: supermarkets, shops, } \\
\text { restaurants. }\end{array}$ & $\begin{array}{l}\text { Organic } \\
\text { labelling }\end{array}$ \\
\hline $\mathrm{CR}$ & Yes & Yes & Yes & $\begin{array}{c}\text { Directly to producers and commercial } \\
\text { network }\end{array}$ & Yes (BtoB) \\
\hline LLV & Yes & Yes & Yes & Directly to florist and commercial network & Yes (BtoB) \\
\hline
\end{tabular}

The modernization of the sector is key to achieving the goals that all producers have expressed: 'quality, sustained production throughout the year and price'. Aspects such as the efficiency in the use of water, fertilization, climate and the use of machinery for specific processes are key to achieve these objectives. The small differences observed between the interviewed farms are due to the needs of specific crops that are cultivated.

There is little use of recirculation systems of nutrient solution on the farms interviewed. Van Oss [29] estimated a saving of $30 \%$ in water and a $40 \%$ in fertilizers in recirculation systems of the nutrient solution with respect to systems without recirculation of nutrient solution. This under-utilisation of the recirculation of nutrient solution seems to be common throughout the industry of ornamental plants and cut flowers.

The level of investment for the modernisation of farms, as commented by some of the producers, is currently lower than in the year 2008, which is explained by the fall in the consumption of plant and ornamental flower which has affected Spain in the past 9 years. For Hernandez et al. [3], this decline in consumption is due to the real estate crisis that has suffered Spain since the year 2007-2008. The crisis has affected the consumption at the level of individuals as well as public administration.

For those companies that have a substantial export level, which often sell to wholesalers across Europe it is important to have a certificate that guarantees the quality of the product and that it has been produced with respect for the standards the environment.

Despite the study area is in a densely populated region, only FBM for cut flowers, and JRM and JRV for edible flowers, sold the $100 \%$ of their production in Catalonia. The rest, either directly or indirectly sell part of their production abroad (Spain or abroad). The decline in domestic consumption of ornamental plants and cut flowers in recent years due to the crisis is one of the reasons for which many farms exported part of their production. The highest 
spending per person of ornamental plants and cut flowers in other European markets, (such as German), where it can reach $37 €$ per person per year [30], makes these markets more attractive for the Maresme producers. The producers that are taking advantage of the European market, are the potted plant producers. They have less competition from outside the European Union markets because of the difficulty in transport. Proof of this is that potted plant producers sell between $30-50 \%$ of its production abroad.

\section{CONCLUSION}

The small size of the farms in the area of study offers few alternatives to the economic viability of these farms. The specialization in one product, such as the ornamental plant and flower, is one of the strategies. Ornamental crops have a high value of production for unit of surface. These high revenues are useful for urban farmers, located in densely populated areas where the price of land for farms is very high for the opportunity cost of land, when compared with other urban soil uses. The $77 \%$ of the farm holdings studied have a production value over $100,000 €$ per year. All the farmers interviewed invest every year an amount of money in their holding. This is a good indicator that they do not think of closing their agrarian activity.

The farmers, to achieve their goals of quality, price and continuous production during all year, have a high degree of specialization such us cut flowers, green foliage, pot plants and seedlings. They are intensive in the use of technology, which it is essential to compete in a global market and to have a minimum standard of environmental protection. However, according to their answer, the farmers could incorporate systems to recirculate the nutrient solution and renew some old greenhouses structures to improve their water, fertilizer and energy consumption.

Their situation in urban fringe areas is key to these peri-urban farms. Metropolitan Regions are often well connected by road and train. Sometimes there is an international airport or harbour that is useful for the logistics. Cities also offer more facilities to connect these farms to power and gas networks. In the case of Barcelona Metropolitan Region, the ornamental producers are located in an area where the cultivation of ornamental plants and cut flowers has almost 100 years of history. That is an advantage for them because a network of irrigation suppliers and greenhouses material supplies exist in the area and because the study area is recognized as an ornamental production area in Spain and Catalonia.

All the farmers interviewed use the infrastructures associated with the Metropolitan Region for they business model. Their location, very close to the citizens, is crucial to satisfy a local demand of ornamental plants and to sell their production to the rest of Catalonia, Spain and Europe and to receive cuttings and seedlings from all the world.

\section{REFERENCES}

[1] Opitz, I., Specht, K., Berges, R., Siebert, R. \& Piorr, A., Toward sustainability: Novelties, areas of learning and innovation in urban agriculture. Sustainability, 8(4), pp. 1-18, 2016.

[2] Korthals Altes, W.K. \& van Rij, E., Planning the horticultural sector. Managing greenhouse sprawl in The Netherlands. Land Use Policy, 31, pp. 486-497, 2013.

[3] Hernandez, M., Morales, A. \& Sauri, D., Ornamental plants and the production of nature(s) in the Spanish real estate boom and bust: The case of Alicante. Urban Geogr., 35(1), pp. 71-85, 2014.

[4] Huang, L. \& Yeh, T., Floral consumption values for consumer groups with different purchase choices for flowers. HortTechnology, 19(3), pp. 563-571, 2013 
[5] Steen, M., A world of flowers: Dutch flower auctions and the market for cut flowers. J. Appl. Hortic., 12(2), pp. 113-121, 2010.

[6] Tzavaras, M., Tzimitra-Kalogianni, I. \& Bourlakis, M., Consumer behaviour in the Greek floral market: Comparative insights for the food industry. Br. Food J., 112(4), pp. 403-415, 2010.

[7] Chen, N. \& Wei, S., Factors influencing consumers' attitudes towards the consumption of edible flowers. Food Qual. Preference, 56, pp. 93-100, 2017.

[8] Chandler, S. \& Tanaka, Y., Genetic modification in floriculture. Crit. Rev. Plant Sci., 26(4), pp. 169-197, 2007.

[9] Chandler, S.F. \& Brugliera, F., Genetic modification in floriculture. Biotechnol. Lett., 33(2), pp. 207-214, 2011.

[10] Lütken, H., Hegelund, J.N., Himmelboe, M., Lauridsen, U.B. \& Müller, R., Natural transformation in plant breeding - A biotechnological platform for quality improvement of ornamental, agricultural and medicinal plants. Acta. Hortic., 1087, pp. 19-27, 2015.

[11] Van Iersel, M.W., Chappell, M.R. \& Thomas, P.A., Optimizing growth, quality, and profits through precision irrigation in ornamental plant production. Acta. Hortic., 1131, pp. 57-64, 2016.

[12] Saavoss, M., Majsztrik, J., Belayneh, B., Lea-Cox, J. \& Lichtenberg, E., Yield, quality and profitability of sensor-controlled irrigation: a case study of snapdragon (Antirrhinum majus L.) production. Irrig. Sci., 34(5), pp. 409-420, 2016.

[13] Prenafeta-Boldú, F.X., Trillas, I., Viñas, M., Guivernau, M., Cáceres, R. \& Marfà, O., Effectiveness of a full-scale horizontal slow sand filter for controlling phytopathogens in recirculating hydroponics: from microbial isolation to full microbiome assessment. Sci. Total Environ., pp. 599-600, pp. 780-788, 2017.

[14] Kolokotsa, D., Saridakis, G., Dalamagkidis, K., Dolianitis, S. \& Kaliakatsos, I., Development of an intelligent indoor environment and energy management system for greenhouses. Energy Convers. Manage., 51(1), pp. 155-168, 2010.

[15] Proverde. The European market for fair sustainable flowers and plants. Belgian Development Agency and Trade and development centre. https://goo.gl/naDt8j. Accessed on: 17 Dec. 2017.

[16] Mougeot, L.J.A., Urban Agriculture: Definition, presence, potentials and risks, and policy challenges. International Development Research Center, 2000. https://goo.gl/2Nk8Qm. Accessed on: 17 Dec. 2017.

[17] Vejre, H. et al., Jovis: Berlin, pp. 18-21, 2016.

[18] Pölling, B., Sroka, W. \& Mergenthaler, M., Success of urban farming's cityadjustments and business models-Findings from a survey among farmers in Ruhr Metropolis, Germany. Land Use Policy, 69, pp. 372-385, 2017.

[19] Zasada, I., Multifunctional peri-urban agriculture-A review of societal demands and the provision of goods and services by farming. Land Use Policy, 28(4), pp. 639-648, 2011.

[20] Van der Schans, J.W. et al., It is a business! Business models in urban agriculture. Urban Agriculture Europe, eds F. Lohrberg, L. Licka, L. Scazzosi \& A. Timpe, Jovis: Berlin, pp. 82-91, 2016.

[21] Akimowicz, M., Cummings, H. \& Landman, K., Green lights in the Greenbelt? A qualitative analysis of farm investment decision-making in peri-urban Southern Ontario. Land Use Policy, 55, pp. 24-36, 2016.

[22] Departament d'Agricultura, Ramaderia, Pesca i Alimentació. Estadístiques definitives any, 2015. http://agricultura.gencat.cat/ca/departament/dar_estadistiques 
observatoris/dar_estructura_produccio/dar_estadistiques_agricoles/dar_estadistiques definitives. Accessed on: 17 Dec. 2017.

[23] Llobet, S., De geografía agraria de la comarca del Maresme (Barcelona). Estudios Geográficos, 58(16), pp. 23-71, 1955.

[24] Marfà, O., La Flor Tallada al Maresme aspectes econòmics. https://goo.gl/658PGP. Accessed on: 17 Dec. 2017.

[25] Pölling, B., Creating the added value - social benefits of Urban Agriculture. Urban Agriculture Europe, eds F. Lohrberg, L. Licka, L. Scazzosi \& A. Timpe, Jovis: Berlin, pp. 92-105, 2016.

[26] Rubiales, P.M., Jordi Bayona-i-Carrasco e Isabel Pujadas Rúbies. Patrones espaciales de la segregación residencial en la Región Metropolitana de Barcelona: pautas de segregación de los grupos altos. Scripta Nova. www.ub.es/geocrit/sn/sn-423.htm. Accessed on: 17 Dec. 2017.

[27] Ministerio de Agricultura y Pesca, Alimentación y Medio Ambiente. Red Contable Agraria Nacional - Coeficientes de Producción Estándar. http://www.mapama.gob.es/ es/estadistica/temas/estadisticas-agrarias/economia/red-contable-recan/\#para5.

Accessed on: 17 Dec. 2017.

[28] Recasens, X., Alfranca, O. \& Maldonado, L., The adaptation of urban farms to cities: The case of the Alella wine region within the Barcelona Metropolitan Region. Land Use Policy, 56, pp. 158-168, 2016.

[29] Van Os, E.A., Closed soilless growing systems: a sustainable solution for Dutch greenhouse horticulture. Water Sci. Technol., 39(5), pp. 105-112, 1999.

[30] Schettler, C., Rombach, M. \& Bitsch, V., Perceived advantages and barriers of buying cut flowers online. Acta. Hortic., 1132, pp. 9-16, 2016. 